\title{
Black rice anthocyanin content increases with increase in altitude of its plantation
}

\begin{abstract}
Black rice is the most nutritious heirloom rice landraces. A G60 black rice variety was grown in both terai and hill region of Nepal at 79 meters and 1360meter altitude from mean sea level in 2015. The important rice qualities such as total anthocyanin content, caryopsis color, Calcium, and iron content were analyzed. It was observed that the anthocyanin content of black rice increased significantly with increase in altitude of its plantation site. The increase in anthocyanin content may be due to favorable environment and environment genotype interaction. This finding also indicates that some other rice quality may also increase with an increase in altitude of its plantation.
\end{abstract}

Keywords: black rice, anthocyanin, rice quality, genotype xenvironement, quality rice
Volume 5 Issue I - 2016

\author{
Ujjawal Kumar Singh Kushwaha \\ Agriculture Botany Division, Nepal Agricultural Research \\ Council, Lalitpur, Nepal
}

Correspondence: Ujjawal Kumar Singh Kushwaha, Agriculture Botany Division, Nepal Agricultural Research Council, Khumaltar, Lalitpur, Nepal,

Email ujjawalplantbreeder@narc.gov.np

Received: October 16, 2016 | Published: November 10, 2016

\section{Introduction}

Black rice is an heirloom rice landrace mostly grown in China, Korea, Japan, Thailand, Philippines and India. ${ }^{1}$ This rice is highly rated in the market because of its huge nutritional value. ${ }^{2}$ The main peculiarity of black rice is its anthocyanin which is both fat and water soluble. Earlier, it was believed that this rice enhance the longevity of life hence this rice is also known as long life rice. General people were forbidden to consume black rice except for emperiors and nobles in China, thus this rice is popularly known as forbidden rice. There exists no other rice with a higher nutritional spectrum near black rice. This rice is free of gluten, free of cholesterol, low in sugar, salt, and fat. Black rice is a whole grain, super nutritious type of rice that is high in fiber, anthocyanin, antioxidants, vitamins B and E, iron, thiamine, magnesium, niacin and phosphorous. A huge number of scientific studies show that black rice powder is one of the nature's most wellbalanced superfood and its abilities are truly remarkable. Black rice anthocyanins (BRACs) are extracted from the aleurone layer of black rice which is a major cereal crop existing since ancient times in China and other Eastern Asia countries. ${ }^{3}$ American Health Association, the American Cancer Society and the 2005 Dietary Guidelines for Americans recommended an increase in the consumption of black rice to prevent heart disease and certain kinds of cancers. ${ }^{4}$ Black rice contains many vitamins and minerals, including iron, vitamin $\mathrm{A}$, and vitamin $\mathrm{B}$, which are beneficial for overall health and the prevention of heart disease. ${ }^{5}$ The health benefits of black glutinous rice have recently been reported by several investigators. A recent report showed that anthocyanin supplementation in humans improves LDL and HDL levels ${ }^{6}$ and can delay cancer development in rodents models of carcinogenesis. ${ }^{7}$ The main purpose of this study was to compare the black rice quality in different altitudes.

\section{Materials and methods}

Black rice G60 variety was grown in both terai and hill region of Nepal maintaining different altitudes at summer season of 2015. First place was selected as Ramban Sarlahi located at $26^{\circ} 52^{\prime} 0 \mathrm{~N} 85^{\circ} 34^{\prime} 0 \mathrm{E}$ with an altitude of 79 meters (262 feet) in terai region and the second place was chosen as Khumaltar Lalitpur at an altitude of 1360meter above mean sea level on $27040^{\prime} \mathrm{N}$ latitude and $85020^{\prime} \mathrm{E}$ longitudes.
25-28 days old seedlings were transplanted in a $5 \mathrm{mX} 2 \mathrm{~m}$ area with a spacing of $15 \mathrm{cmX} 15 \mathrm{~cm}$ in normally irrigated condition of July 2015 . Fertilizer was recommended @ $10: 40: 30 \mathrm{~kg} / \mathrm{ha}$ and $@ 80: 30: 30 \mathrm{~kg} / \mathrm{ha}$ NPK for both terai and hill regions respectively. The basal dose was applied as $50 \%$ of total nitrogen content, full dose of phosphorus and potassium and the remaining was applied in split dose as a top dress after 1st wedding and at rice booting stage. Agronomic practices were done as per the recommended practices. Different major traits were measured such as days to maturity, plant height, panicle length and grain yield. Rice quality analysis was done in Food and Technology Division, NARC, Khumaltar, Nepal.

\section{Determination of minerals}

The total contents of calcium $(\mathrm{Ca})$ and iron $(\mathrm{Fe})$ were determined in extracts obtained upon mineralization in nitric acid (HNO3 p.a.) with a concentration of $1.40 \mathrm{~g} \cdot \mathrm{cm}^{-1}$ in a MARS 5 microwave oven (CEM Corporation, USA), in HP500 Teflon vessels (the parameters of the process, i.e., weight of analytical samples, volume of nitric acid, and temperature of the mineralization process complied with the US-EPA3051 Protocol). Total concentrations of the six analyzed metals were determined by using an inductively coupled plasma (ICP) atomic emission spectrometer (IRISIntrepidXSPII, Thermo, USA). The analysis by use of an ICP atomic emission spectrometer (ICPAES) was conducted after preparing the standard calibration curves corresponding to each element. Mean and SD were calculated.

\section{Results and discussion}

The average days to rice heading and maturity of black rice were 83 days and 129 days at 1360 meter height whereas days to heading and maturity at $79 \mathrm{~m}$ were 7 days and 116days. The longer days to maturity in hill region may be due to low solar radiation and low growing degree days compared to terai region. Some other rice parameters like plant height and tiller number did not differ significantly from both sites. Similarly, the grain yield of different rice varieties also varies with different locations. Grain yield was found higher in high altitude compared to low altitude. The increase in grain yield in high altitude is due to longer duration of photosynthesis uptake by plants compared to terai region. Similar results were also found by Kushwaha et al. ${ }^{8}$ 
and Khakwani et al.,' who suggested that highest paddy yields are obtained in early transplanting. The reason could be that this might be due genotype genetic superiority, an appropriate temperature for growth and development, nutrients absorption, the proper root system of the genotype and proper time of transplanting which leads to providing optimum duration for seed filling. The mineral content $(\mathrm{Ca}$ and $\mathrm{Fe}$ ) of black rice from different two locations were analyzed and no significant difference was found from both altitude of plantations. But black rice possessed more $\mathrm{Ca}$ and $\mathrm{Fe}$ than other rice varieties. Kushwaha ${ }^{8}$ also reported that black rice contains a huge amount of minerals than other rice varieties. Chen et al., ${ }^{10}$ reported that red and black rice both contained higher total phenols content than white rice. Therefore, it is reasonable to presume that the higher amounts of minerals in red and black rice derive from a phenolic compound

Table I Rice different parameters are taken during rice growing season of 2015 at 1360meter under high hill observation nursery trial at Agriculture Botany Division, Khumaltar, Nepal

\begin{tabular}{lllllll}
\hline S.No & Genotypes & Days to heading & Days to maturity & Plant height & Tiller number & Grain yield \\
\hline 1 & Karo & 99 & 140 & 118.8 & 11.2 & 6.07 \\
2 & Darmali & 99 & 141 & 114.8 & 13 & 6.33 \\
3 & Salidhan & 94 & $13 \mid$ & 124 & 11.8 & 5.77 \\
4 & chandannath-3 & 89 & $13 \mid$ & 125 & 13.6 & 4.56 \\
5 & Lekali-3 & 90 & 133 & 122.2 & 0 & 6.11 \\
6 & Black rice (G60) & 83 & 129 & 57.6 & 0 & 3.81 \\
7 & 98046-TRI96-2-I-1 & 88 & 133 & 86.2 & 19 & 6.8 \\
\hline
\end{tabular}

Table 2 Rice different parameters are taken during rice growing season of 2015 at 79 meter level at Ramban Sarlahi Nepal

\begin{tabular}{|c|c|c|c|c|c|c|}
\hline S.No & Genotypes & Days to heading & Days to maturity & Plant height & Tiller number & Grain yield \\
\hline 1 & Karo & 80 & 125 & 115.5 & 10 & 4.05 \\
\hline 2 & Darmali & 82 & 122 & 110.8 & 11 & 4.33 \\
\hline 3 & Salidhan & 85 & 118 & 112 & 10 & 5 \\
\hline 4 & chandannath-3 & 84 & 120 & 115 & 12 & 4.5 \\
\hline 5 & Lekali-3 & 83 & 116 & 121 & 14 & 6 \\
\hline 6 & Black rice (G60) & 78 & 116 & 67 & 11 & 3 \\
\hline 7 & 98046-TR I96-2-I-I & 82 & 119 & 89 & 13 & 4.8 \\
\hline
\end{tabular}

Table 3 Content of two mineral elements in different locations with different varieties

\begin{tabular}{|c|c|c|c|c|}
\hline \multicolumn{2}{|c|}{ Khumaltar (1360 meter) } & \multicolumn{3}{|c|}{ Ramban (79 meter) } \\
\hline Cultivars & $\mathrm{Ca}(\mathrm{mg} / 100 \mathrm{~g})$ & $\mathrm{Fe}(\mathrm{mg} / 100 \mathrm{~g})$ & $\mathrm{Ca}(\mathrm{mg} / / 00 \mathrm{~g})$ & $\mathrm{Fe}(\mathrm{mg} / \mathrm{l} 00 \mathrm{~g})$ \\
\hline Blackrice G60 & $53.0 I \pm I .82 h$ & $5.90 \pm 1.43 \mathrm{~d}$ & $52.60 \pm 0.19 a$ & $5.02 \pm 4.4 \mathrm{le}$ \\
\hline Karo & $20.29 \pm 1.49 c$ & $10.35 \pm 2.15 f$ & $19 \pm 1.24 b$ & $8.35 \pm 4.03 f$ \\
\hline Darmali & $53.27 \pm 54.74 \mathrm{~g}$ & $3.67 \pm 0.95 c$ & $5 \mathrm{I} .80 \pm 0.2 \mathrm{lb}$ & $3.00 \pm 7.08 \mathrm{~g}$ \\
\hline Salidhan & $20.34 \pm 1.33 b$ & $4.24 \pm 1.40 \mathrm{~b}$ & $18.02 \pm 0.38 \mathrm{~d}$ & $4.45 \pm 2.32 b$ \\
\hline Chandannath-3 & $20.56 \pm 3.16 a$ & $8.56 \pm 2.6 \mathrm{le}$ & $19.21 \pm 3.37 d$ & $7.30 \pm 2.4 \mathrm{Ih}$ \\
\hline Lekali Dhan-3 & $30.47 \pm 2.4 \mathrm{If}$ & $4.24 \pm 0.97 a$ & $30.37 \pm 0.82 b c$ & $4.54 \pm 4.56 c$ \\
\hline 98046-TRI96-2-I-I & $26.69 \pm 3.02 \mathrm{e}$ & $1.44 \pm 0.76 a$ & $25.24 \pm 0.79 b$ & $1.04 \pm 1.30 \mathrm{a}$ \\
\hline
\end{tabular}


Table 4 Total anthocyanin content and caryopsis color of different rice varieties at different altitudes

\begin{tabular}{|c|c|c|c|c|}
\hline \multicolumn{2}{|c|}{ Khumaltar (I360 meter) } & \multicolumn{3}{|c|}{ Ramban (79 meter) } \\
\hline Cultivars & Total Anthocyanin Content & Caryopsis Colour & Total Anthocyanin Content & Caryopsis Colour \\
\hline Blackrice756 & $3.93 \pm 0.12 \mathrm{a}$ & Dark black & $2.03 \pm 0.12 a$ & Light Black \\
\hline Karo & $0.8 \mathrm{I} \pm 0.76 \mathrm{~d}$ & White & $0.8 I \pm 0.76 \mathrm{~d}$ & White \\
\hline Darmali & $0.76 \pm 0.69 a$ & White & $0.76 \pm 0.69 a$ & White \\
\hline Salidhan & $0.69 \pm 0.7 \mathrm{lbc}$ & White & $0.69 \pm 0.7 \mathrm{lbc}$ & White \\
\hline Chandannath-3 & $0.02 \pm 0.34 b$ & White & $0.02 \pm 0.34 b$ & White \\
\hline Lekai Dhan-3 & $0.87 \pm 1.06 c$ & White & $0.87 \pm 1.06 c$ & White \\
\hline 98046-TR I96-2-I-I & $0.38 \pm 0.03 \mathrm{bc}$ & White & $0.38 \pm 0.03 b c$ & White \\
\hline
\end{tabular}
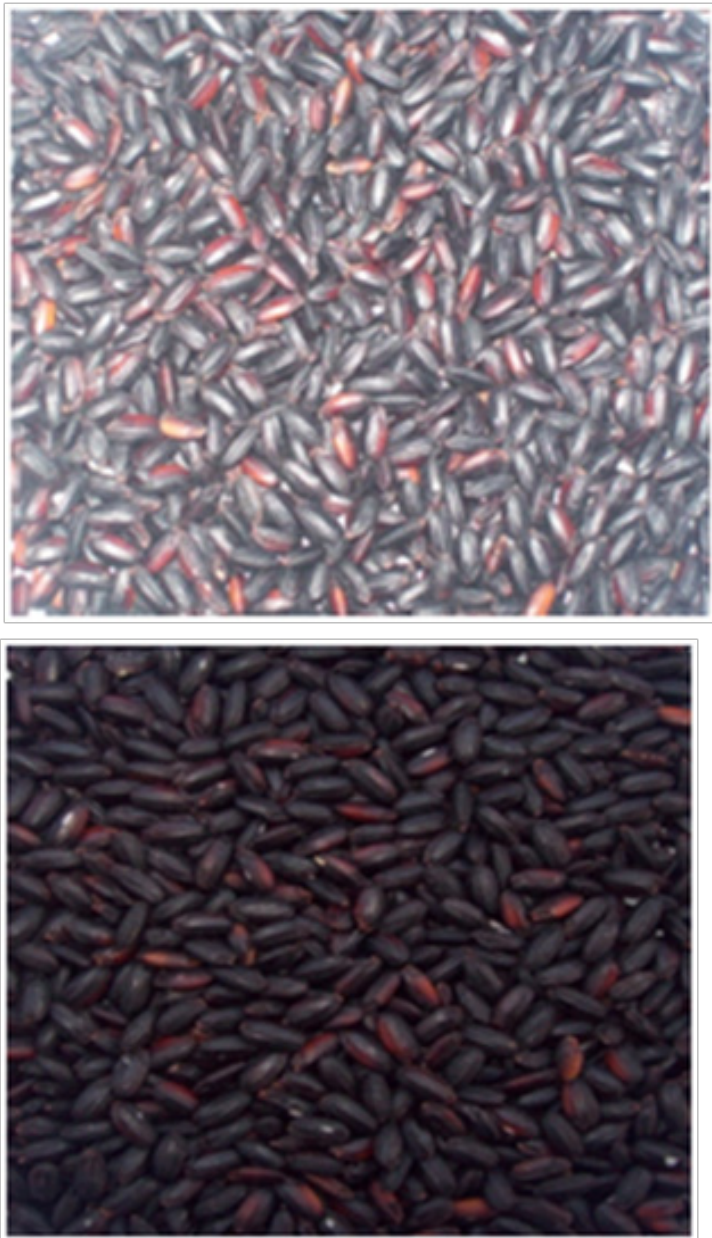

Figure I Black rice caryopsis color (I-light dark and 2-heavy dark) from 79m and $1360 \mathrm{~m}$ altitude from mean sea level respectively.

\section{Conclusion}

Black rice is packed with high nutrition. Among several rice quality, anthocyanin is the one which causes black rice color black.
The results reveal that black rice anthocyanin content increase with an increase in altitude of its plantation with a favourable environment.

\section{Acknowledgements}

None.

\section{Conflict of interest}

The author declares no conflict of interest.

\section{References}

1. Kong L, Wang Y, Cao Y. Determination of Myo-inositol and D-chiroinositol in black rice bran by capillary electrophoresis with electrochemical detection. J Food Composition and Analysis. 2008;21(6):501-504.

2. Kushwaha UKS, Khatiwada SP, Upreti HK, et al. Delayed transplanting of aged rice seedlings cause the yield reduction in farmer's field. Genomics and Applied Biology. 2016;7(1):1-9.

3. Ling WH, Wang LL, Ma J. Supplementation of the black rice outer layer fraction to rabbits decrease atherosclerotic plaque formation and increases antioxidant status. $J$ Nutr. 2002;132(1):20-26.

4. USA Rice Federation.

5. Chen CC, Hsu JD, Wang SF, et al. Hibiscus sabdariffa extract inhibits the development of atherosclerosis in cholesterol-fed rabbits. J Agric Food Chem. 2003;51(18):5472-5477.

6. Qin Y, Xia M, Ma J, et al. Anthocyanin supplementation improves serum LDL and HDL-cholesterol concentrations associated with the inhibition of cholesteryl ester transfer protein in dyslipidemic subjects. Am J Clin Nutr. 2009;90(3):485-492.

7. Thomasset S, Teller N, Cai H, et al. Do anthocyanins and anthocyanidins, cancer chemopreventive pigments in the diet, merit development as potential drugs? Cancer Chemother Pharmacol. 2009;64(1):201-211.

8. Kushwaha UKS. Black Rice-Research, History, and Development. Switzerland: Springer International Publishing; 2016. p. 21-47.

9. Khakwani AA, Zubair M, Mansoor M, et al. Agronomic and morphological parameters of rice crop as affected by date of transplanting. J Agron. 2006;5(2):248-250.

10. Chen XQ, Nagao N, ItaniT, et al. Anti-oxidative analysis, and identification and quantification of anthocyanin pigments in different colored rice. Food Chemistry. 2012;135(12):2783-2788. 
11. Shen Y, Jin L, Xiao P, et al. Total phenolics, flavonoids, antioxidant capacity in rice grain and their relation to grain color size and weight. Journal of Cereal Science. 2009;49(1):106-111.

12. Sompong R, Siebenhandl ES, Linsberger MG, et al. Physicochemical and antioxidative properties of red and black rice varieties from Thailand, China, and Sri Lanka. Food Chemistry. 2011;124(1):132-140.
13. Finocchiaro F, Ferrari B, Gianinetti A. A study of biodiversity of flavonoid content in the rice caryopsis evidencing simultaneous accumulation of anthocyanins and proanthocyanidins in a black-grained genotype. $J$ Cereal Sci. 2010;51(1):28-34. 